\title{
Effects of royal jelly and honey mixture on some hormones in young males performing maximal strength workout
}

\author{
Büyükipekçi S. ${ }^{1 \mathrm{ABCDE}}$, Sarıtaş N. ${ }^{2 \mathrm{ABCDE}}$, Soylu M. ${ }^{3 \mathrm{ABCDE}}$, Mistık S. ${ }^{4 \mathrm{ABCDE}}$, Silici S. ${ }^{5 \mathrm{ABCDE}}$ \\ ${ }^{1}$ Meram Vocational School, Necmettin Erbakan University, Konya, Turkey \\ ${ }^{2}$ Sports Sciences Faculty, Erciyes University, Kayseri, Turkey \\ ${ }^{3}$ Faculty of Health Sciences, Department of Nutrition and Dietetics, Biruni University, Istanbul, Turkey \\ ${ }^{4}$ Medical Faculty, Family Medicine Department, Erciyes University, Kayseri, Turkey \\ ${ }^{5}$ Faculty of Agriculture, Department of Agricultural Biotechnology, Erciyes University, Kayseri, Turkey
}

Authors' Contribution: A - Study design; B - Data collection; C - Statistical analysis; D - Manuscript Preparation; E - Funds Collection.

\begin{abstract}
Purpose: $\quad$ Among products used as ergogenic substances by sportsmen, royal jelly and honey have attracted attention in recent years. This study was carried out to determine the effect of royal-jelly and honey mixture on weight lifting performances and some hormone test of athletes.

Material: $\quad$ Randomly selected healthy 29 athletes, aged between 20 and 25 years, were divided into two groups. Placebo (corn starch) was given to the Control Group and 5 grams of royal jelly +45 grams of honey mixture was given to the experimental group for eight weeks. After one week of weight adjustment workout; maximum weight (bench press, shoulder press, squat, deadlift and arm curl movements) that each athlete can lift was determined and hormones (Free T4, Free T3, Cortisol, Insulin, Total Testosterone and ACHT, TSH, Growth Hormone, Prolocatin, FSH, LH) were examined at pro-exercise, after four weeks of exercise, and after eight weeks of exercise.

Results: $\quad$ As a result of the study, a statistical increase in the weights lifted in the bench press, squat, arm curl, deadlifts and shoulder press movements in the second and third measurements with respect to the first measurement was determined within both groups $(p<0.001)$. While according to the hormone test results in placebo and experimental groups, there was no significant difference in free $\mathrm{T} 3$, total testosterone variables intra-groups and inter-groups ( $p>0.05$ ), but there was significant difference in free T4 value in 2. measurements of groups $(p=0.030)$ and between the 2 . and 3. measurements in the test group in the variable of insulin hormone ( $p$ $<0.001$ ).

Conclusions: In conclusion, it is thought that in young males performing maximal strength workout, royal jelly + honey supplement does not affect the increase in weight lifted, this increase is due to the weight training applied, but it causes some hormone changes.

Keywords: exercise, performance, nutrition, royal jelly, honey, ergogenic aid.
\end{abstract}

\section{Introduction}

The use of substances, methods and materials other than natural ability and training in order to improve sportive performance is called ergogenic aid. For many athletes, winning is the only goal. As long as moments, millimeters, grams are important to gain and lose, the use of methods or materials that will improve performance will also be important.

Among products used as ergogenic substances by sportsmen, royal jelly and honey have attracted attention in recent years. Royal jelly is a bee product in a creamy structure secreted by young worker honey bees. Average moisture content of royal jelly is $60-70 \%$; crude proteins are $12-15 \%$, lipids are $3-6 \%$, sugar is $10-16 \%$, and lowmolecular-weight compounds (vitamins such as vitamin $\mathrm{E}$, biotin, folic acid, inositol, niacin, pantothenic acid, pyridoxine, riboflavin, thiamine, and minerals such as copper, zinc, iron, calcium, manganese, potassium, sodium and free amino acids) are $2-3 \%$ [1].

It has been determined that footballers who took royal jelly to have a higher average in terms of body

\footnotetext{
(C) Büyükipekçi S., Sarıtaş N., Soylu M., Mıstık S., Silici S., 2018 doi:10.15561/20755279.2018.0605
}

height, body mass, muscle and bone component [2]. In another study they have determined that serum amino acid content, BUN, and creatine levels, which are of the biochemical parameters of the athletes, were influenced when they give royal jelly to 40 male swimmers between the ages of 18-25 [3].

Among the bee products, the most known is honey and carbohydrates are the main components that make up about $95 \%$ of the dry weight. For this reason it is an important source of energy for athletes. It contains carbohydrates as well as biologically important compounds such as organic acids, proteins, amino acids, minerals, phenolic compounds, vitamins, minerals and aroma compounds and has beneficial health effects [4].

The stress formed on the human organism by the exercise has a variety of physiological and metabolic effects on the tissues such as blood [5]. It is stated that these differences depend on the intensity, duration, frequency of exercise and physical, physiological and conditional state of the subjects participating in the study [6]. For this reason, athletes practice various resistance exercises with the aim of increasing their general strengths, such as weight lifting exercises, which are powerful stimuli for the muscular nervous system [7]. It is 
reported that changes in blood concentrations of various hormones during or after exercise may occur depending on the duration of the training and it is necessary to know the hormonal responses to the exercise [8].

This study was aimed to determine the effect of royaljelly and honey mixture on weight lifting performances and some hormones of athletes, considering that royal-jelly and honey mixture performing maximal weight workout may increase the strength and muscle development in motoric characteristics of the athletes.

\section{Materials and Method}

Participants: 30 male volunteers attending Erciyes University School of Physical Education and Sports participated in this study. Randomly selected healthy 30 students, aged between 20 and 25 years, were divided into two groups; placebo (corn starch) was given to the Control Group and honey mixture was given to the experimental group. After the trial started, since 1 student in the experimental group left the study because of some reasons; the study continued with a total of 29 volunteer students, with 14 students of experimental group and 15 students of control group.

Research Design: The 14 volunteers in the experimental group were given 5 grams of royal jelly +45 grams of honey, a total of 50 grams of mixture provided from Altiparmak Co, for 8 weeks and 20-30 minutes before breakfast. 15 volunteers in the control group received 50 grams of placebo (corn starch) in the same way. Body weight was measured with athletes in the standard sportswear, with a bias of $\pm 100 \mathrm{gr}$ (Tanita TBF 401 A Japan) in the upright position. Stature measurement was performed in the Frankfort plane with the wall mounted measure while the feet were naked. The body mass index was obtained by dividing body weight by length in meters, and was classified according to WHO criteria [9].

After a week of weight adjustment exercises, the maximum weight lifting weight that each athlete could lift was determined and the athletes were taken to work out after 10 minutes of running and stretching exercises. The weight training sets were formed by the movements of the bench press, shoulder press, squat, deadlift and arm curl, the series were formed by weight lifting determined for each of the athletes, with lifting $80 \%$ of maximum weight for 7 times, $85 \%$ for 5 times, $90 \%$ for 3 times, $95 \%$ for 2 times, and $100 \%$ for 1 time. The weight exercises were continued for 2 months ( 8 weeks), 4 days a week, 2 hours a day with intervals of 3-5 minutes between sets and with intervals of 3 minutes between the series. Athletes were subjected to a pyramid training program that began with $80 \%$ capacity, reached $100 \%$ capacity and returned again to $80 \%$ capacity.

Before starting to work, blood samples were taken from the volunteers in medical college blood donor unit between 08: 00-09: $00 \mathrm{am}$ in the morning of 4th and 8th weeks from the start of the study with empty stomach and analyzes were made.

Blood samples taken were analyzed in Erciyes
University Hospital Central Laboratory over service procurement. Free T4, Free T3, Cortisol, Insulin, Total Testosterone and ACHT, TSH, Growth Hormone, Prolactin, FSH, LH hormones were examined. Hormone Tests were evaluated by Siemens Advia Centaur XP Immunoassay System.

Statistical Analysis: SPSS software package was used for statistical evaluation of the data obtained in the study. The normality test of the variables was tested with the shapiro-wilk test. Nonparametric tests were used because variables which were not normally distributed did not fulfill parametric test assumptions. Statistical notations are expressed as median (25th percentile 75 th percentile). The Mann-Whitney U test was used to compare differences between groups, and the Friedman test was used to analyze statistical changes over time. The Dunn-Bonferroni test was performed as a post hoc test. Significance level was taken as $\mathrm{p}<0.05$.

For the research, ethics committee permission with number 2012/567 and date 07/8/2012 was obtained from Erciyes University Deanship of Faculty of Medicine and all volunteers were informed about the project and consent form was obtained from all volunteers.

\section{Results}

There were no significant differences found in terms of age, height, body weight, body mass and index values both in time and between the groups for both the placebo and the experimental groups participating in the study ( $\mathrm{p}$ $>0.05$ ) (Table 1).

In 2. and 3. measurements $(\mathrm{p}<0.05)$ in the inter-group bench press $(\mathrm{kg})$, in $1 ., 2$. and 3. measurements $(\mathrm{p}<0.05)$, in squat $(\mathrm{kg})$, in 2 . measurement $(\mathrm{p}<0.05)$, in arm curl and in 2 . measurement $(\mathrm{p}<0.05)$ in the shoulder press, the inter-group differences were found to be significant $(\mathrm{p}<0.05)$. There was no inter-group difference in the Deadlifts movement ( $\mathrm{p}>0.05)$.

In both groups, a statistically significant increase was found in the weights lifted in the bench press, squat, arm curl, deadlifts and shoulder press movements in the second and third measurements with respect to the first measurement and it was determined that the differences between all measurements were significant $(p<0.001)$ (Table 2).

There was no significant difference in free T3, total testosterone hormones between the placebo and experimental groups $(p>0.05)$. It was determined that the difference in free T4 values at the second measurement of the groups $(p=0.030)$ was significant.

According to the multiple comparison test (intragroup), there was no significant difference between 1 . and 2., 1st and 3rd measurements in the insulin hormone test group, but the difference between 2. and 3. measurements was found to be statistically significant $(p<0.001)$. In cortisol hormone, the difference between the 1 . and 3 . measurements in the placebo group $(p=0.042)$ was significant (Table 3 ).

There was no significant difference in ACTH, $\mathrm{TSH}$, growth hormone, prolactin and LH hormones 
Table 1. Characteristics of the control and experimental group

\begin{tabular}{lllll}
\hline Variable & Time & $\begin{array}{l}\text { Placebo }(\mathbf{n}=\mathbf{1 5}) \\
\text { Median (25-75\%) }\end{array}$ & $\begin{array}{l}\text { Royal Jelly }(\mathbf{n}=14) \\
\text { Median (25-75\%) }\end{array}$ & P* \\
\hline Age (Years) & 1 & $23(21-24)$ & $22(21-22.25)$ & 0.136 \\
Stature (cm) & 1 & $174(169-178)$ & $173.5(170.75-186)$ & 0.469 \\
& 1 & $66.10(62.20-74.70)$ & $77.25(65.43-87.60)$ & 0.071 \\
Body weight $(\mathrm{kg})$ & 2 & $66.30(63-74.30)$ & $78.45(65.30-85.55)$ & 0.070 \\
& 3 & $66.60(62.10-74.50)$ & $78.80(66.73-86.20)$ & 0.046 \\
BMI $\left(\mathrm{kg} / \mathrm{m}^{2}\right)$ & 1 & $21.70(20.80-23.30)$ & $23.25(21.70-26.63)$ & 0.148 \\
& 2 & $21.60(20.90-23.50)$ & $22.95(21.38-26.90)$ & 0.142 \\
& 3 & $21.50(21-23.60)$ & $23.40(21.73-26.53)$ & 0.095 \\
\hline
\end{tabular}

$\mathrm{P}$ \#: intra-group comparison (Friedman test), $\mathrm{P}$ *: inter-group comparison (Mann-Whitney $U$ test), Median, (25p-75p) $=(25$ percentile-75 percentile) $1=$ pro-exercise, $2=$ after 4 weeks of exercise, $3=$ after 8 weeks of exercise.

Table 2. Comparison of bench press, squat, arm curls, deadlifts and shoulder press movements of the groups

\begin{tabular}{|c|c|c|c|c|}
\hline Variable & Time & $\begin{array}{l}\text { Placebo } \\
\text { Median (25p-75p) }\end{array}$ & $\begin{array}{l}\text { Experiment } \\
\text { Median (25p-75p) }\end{array}$ & $P^{*}$ \\
\hline \multirow{4}{*}{ Bench press (kg) } & 1 & $50.0(47.0-50.0)^{a}$ & $52.0(48.5-65.0)^{\mathrm{a}}$ & 0.149 \\
\hline & 2 & $56.0(49.0-58.0)^{\mathrm{b}}$ & $61.0(56.3-70.3)^{b}$ & $0.028 *$ \\
\hline & 3 & $59.0(56.0-69.0)^{c}$ & $70.0(61.5-75.5)^{c}$ & $0.028 *$ \\
\hline & P\# & $p<0.001$ & $p<0.001$ & \\
\hline \multirow{4}{*}{ Squat (kg) } & 1 & $70.0(70.0-80.0)^{a}$ & $80.5(79.3-95.5)^{a}$ & $0.003 *$ \\
\hline & 2 & $78.0(73.0-85.0)^{\mathrm{b}}$ & $90.0(84.8-106.3)^{b}$ & $0.001 *$ \\
\hline & 3 & $85.0(80.0-92.0)^{c}$ & $99.0(92.0-115.0)^{c}$ & $0.001 *$ \\
\hline & P\# & $p<0.001$ & $p<0.001$ & \\
\hline \multirow{4}{*}{ Arm Curls (kg) } & 1 & $30.0(30.0-32.0)^{a}$ & $33.0(28.3-40.0)^{a}$ & 0.230 \\
\hline & 2 & $34.0(32.0-37.0)^{\mathrm{b}}$ & $39.5(33.8-43.0)^{b}$ & $0.039 *$ \\
\hline & 3 & $38.0(36.0-41.0)^{c}$ & $42.0(37.5-46.0)^{c}$ & 0.094 \\
\hline & P\# & $p<0.001$ & $p<0.001$ & \\
\hline \multirow{4}{*}{ Deadlifts (kg) } & 1 & $70.0(58.0-86.0)^{a}$ & $78.5(73.8-83.0)^{a}$ & 0.136 \\
\hline & 2 & $75.0(62.0-88.0)^{\mathrm{b}}$ & $82.0(79.5-90.0)^{b}$ & 0.220 \\
\hline & 3 & $80.0(66.0-91.0)^{c}$ & $90.0(85.0-96.5)^{c}$ & 0.095 \\
\hline & P\# & $p<0.001$ & $p<0.001$ & \\
\hline \multirow{4}{*}{ Shoulder Press (kg) } & 1 & $35.0(30.0-39.0)^{a}$ & $38.5(34.3-42.8)^{\mathrm{a}}$ & 0.057 \\
\hline & 2 & $38.0(34.0-41.0)^{b}$ & $42.5(39.8-46.0)^{b}$ & $0.023 *$ \\
\hline & 3 & $42.0(37.0-46.0)^{c}$ & $46.5(41.8-49.5)^{c}$ & 0.052 \\
\hline & P\# & $p<0.001$ & $p<0.001$ & \\
\hline
\end{tabular}

abc: If the alphabetical upper symbols in the same column carry separate letters, this indicates the significance of difference between the groups $\mathrm{P} \#$ : intra-group comparison (Friedman test), $\mathrm{P} *$ : inter-group comparison (MannWhitney $U$ test $)$, Median, $(25 p-75 p)=(25$ percentile-75 percentile $) 1=$ pro - exercise, $2=$ after 4 weeks of exercise, 3 $=$ after 8 weeks of exercise.

between the placebo and experimental groups ( $p>0.05)$. According to the multiple comparison test (intra-group), in experimental group in $\mathrm{FSH}$, the difference between 1 . and 3. measurements $(p=0.030)$ was determined to be significant (Table 4)

\section{Discussion}

When the researches are examined, it is observed that the number of researches related to use of royal jelly and honey in exercise and sports studies is very low. The lack of such studies in the literature raises the importance of our study and limits the discussion of the results. For this reason our research results are compared with other ergogenic support products.

In the majority of previous studies made with voluntary individuals; since energy expenditures due to nutrient and energy intakes would be different due to having free living conditions, nutrient uptake was recorded for one week at the beginning of the study and carbohydrate, fat, protein and total energy intake of the control and experimental groups at the beginning of the study did not show any statistical difference. In this study, it was determined 
Table 3. Comparison of hormonal changes of the groups

\begin{tabular}{|c|c|c|c|c|}
\hline Variable & Time & $\begin{array}{l}\text { Placebo } \\
\text { Median (25p-75p) }\end{array}$ & $\begin{array}{l}\text { Experiment } \\
\text { Median (25p-75p) }\end{array}$ & $P^{*}$ \\
\hline \multirow{4}{*}{ Free T4 (ng/dL) } & 1 & $1.16(1.10-1.24)$ & $1.09(1.02-1.20)$ & 0.148 \\
\hline & 2 & 1.26 (1.15-1.39) & $1.18(1.08-1.24)$ & $0.030 *$ \\
\hline & 3 & $1.24(1.17-1.32)$ & $1.21(1.08-1.23)$ & 0.154 \\
\hline & P\# & 0.131 & 0.055 & \\
\hline \multirow{4}{*}{ Free T3 $(\mathrm{pg} / \mathrm{mL})$} & 1 & $3.66(3.55-3.84)$ & $3.70(3.51-3.88)$ & 0.991 \\
\hline & 2 & $3.80(3.56-3.90)$ & $3.77(3.39-3.99)$ & 0.821 \\
\hline & 3 & $3.72(3.55-3.88)$ & $3.68(3.44-3.82)$ & 0.525 \\
\hline & P\# & 0.709 & 0.925 & \\
\hline \multirow{4}{*}{ Cortisol (ug/dL) } & 1 & $12.00(9.15-15.80)^{a}$ & 15.15 (11.75-19.18) & 0.077 \\
\hline & 2 & $17.70(11.80-20.50)^{b}$ & 17.10 (14.55-20.15) & 0.880 \\
\hline & 3 & $16.00(15.00-18.10)^{b}$ & 17.05 (14.78-19.08) & 0.431 \\
\hline & P\# & $0.042 *$ & 0.242 & \\
\hline \multirow{4}{*}{ Insulin (ulU/mL) } & 1 & $5.39(3.39-8.54)$ & $6.68(3.35-9.01)^{a b}$ & 0.612 \\
\hline & 2 & $4.40(2.34-7.02)$ & $3.42(2.18-6.75)^{a}$ & 0.682 \\
\hline & 3 & $5.67(4.20-16.80)$ & $7.23(4.83-11.78)^{b}$ & 0.583 \\
\hline & P\# & 1.000 & $p<0.001$ & \\
\hline \multirow{4}{*}{ Total Testosterone (ng/dL) } & 1 & $453.00(322.00-643.00)$ & $406.50(363.25-574.75)$ & 0.871 \\
\hline & 2 & $490.00(438.00-550.00)$ & $432.50(395.25-535.75)$ & 0.270 \\
\hline & 3 & $446.00(356.00-513.00)$ & $430.50(334.00-580.25)$ & 0.872 \\
\hline & P\# & 0.369 & 0.874 & \\
\hline
\end{tabular}

abc: If the alphabetical upper symbols in the same column carry the separate letter, this indicates the significance of inter-group difference. $\mathrm{P} \#$ : intra-group comparison (Friedman test), $\mathrm{P}$ *: inter-group comparison (Mann-Whitney $U$ test $)$, Median, $(25 p-75 p)=(25$ percentile- 75 percentile $) 1=$ pro- exercise, $2=$ after 4 weeks of exercise, $3=$ after 8 weeks of exercise, $\mathrm{T} 3=$ Triiodothyronine, $\mathrm{T} 4$ = Thyroxine.

Table 4. Comparison of adenohypophyse hormone variables of the groups

\begin{tabular}{|c|c|c|c|c|}
\hline Variable & Time & $\begin{array}{l}\text { Placebo } \\
\text { Median (25p-75p) }\end{array}$ & $\begin{array}{l}\text { Experiment } \\
\text { Median (25p-75p) }\end{array}$ & $P^{*}$ \\
\hline \multirow{4}{*}{ ACTH $(p g / m L)$} & 1 & 18.90 (17.10-37.70) & $28.60(21.60-41.05)$ & 0.201 \\
\hline & 2 & $26.70(18.40-34.10)$ & 29.15 (21.43-36.05) & 0.747 \\
\hline & 3 & $24.40(20.90-37.50)$ & $36.00(25.75-45.80)$ & 0.085 \\
\hline & $\mathrm{P \#}$ & 0.077 & 0.242 & \\
\hline \multirow{4}{*}{ TSH ( $\mu \mathrm{U} / \mathrm{mL})$} & 1 & $2.09(1.13-4.45)$ & $2.18(1.66-3.06)$ & 0.813 \\
\hline & 2 & $2.96(1.75-3.42)$ & $1.84(1.42-2.39)$ & 0.134 \\
\hline & 3 & $2.23(1.11-3.65)$ & $2.25(1.75-3.36)$ & 0.983 \\
\hline & $\mathrm{P \#}$ & 0.077 & 0.116 & \\
\hline \multirow{4}{*}{ Growth Hormone (ng/mL) } & 1 & $0.07(0.06-0.19)$ & $0.10(0.05-0.22)$ & 0.804 \\
\hline & 2 & 0.09 (0.05-0.19) & $0.08(0.05-0.15)$ & 0.785 \\
\hline & 3 & $0.13(0.05-0.22)$ & $0.09(0.05-0.14)$ & 0.181 \\
\hline & $\mathrm{P \#}$ & 0.675 & 0.429 & \\
\hline \multirow{4}{*}{ Prolactin (ng/mL) } & 1 & 7.70 (5.99-12.04) & 9.72 (7.40-14.09) & 0.093 \\
\hline & 2 & $9.20(7.09-11.57)$ & $7.60(6.26-11.80)$ & 0.290 \\
\hline & 3 & $9.13(7.42-10.41)$ & $9.33(6.82-14.33)$ & 0.598 \\
\hline & $\mathrm{P \#}$ & 0.711 & 0.063 & \\
\hline \multirow{4}{*}{$\mathrm{FSH}(\mathrm{mIU} / \mathrm{mL})$} & 1 & $2.63(2.07-3.06)$ & $3.43(1.94-4.12)^{a}$ & 0.230 \\
\hline & 2 & $2.21(1.87-3.36)$ & $3.42(1.66-4.66)^{\mathrm{ab}}$ & 0.158 \\
\hline & 3 & $2.63(2.18-3.65)$ & $3.91(2.22-5.17)^{\mathrm{b}}$ & 0.131 \\
\hline & $\mathrm{P \#}$ & 0.146 & $0.033^{*}$ & \\
\hline \multirow{4}{*}{$\mathrm{LH}(\mathrm{mlU} / \mathrm{mL})$} & 1 & $3.67(2.78-4.33)$ & $4.48(3.07-5.11)$ & 0.444 \\
\hline & 2 & $3.72(3.20-6.31)$ & $3.79(2.70-5.69)$ & 0.747 \\
\hline & 3 & $4.05(2.98-5.13)$ & $5.03(231-6.60)$ & 0.326 \\
\hline & P\# & 0.882 & 0.063 & \\
\hline
\end{tabular}

abc: If the alphabetical upper symbols in the same column carry the separate letter, this indicates the significance of inter-group difference. $\mathrm{P} \#$ : intra-group comparison (Friedman test), $\mathrm{P} *$ : inter-group comparison (Mann-Whitney $\mathrm{U}$ test), Median, $(25 p-75 p)=(25$ percentile-75 percentile) $1=$ pro- exercise, $2=$ after 4 weeks of exercise, $3=$ after 8 weeks of exercise,$=\mathrm{ACTH}=$ Adrenocorticotropic hormone, $\mathrm{TSH}=$ Thyroid stimulated hormone, FSH = Follicle stimulated hormone, $\mathrm{LH}=$ Luteinizing hormone. 
that there was no significant inter-group and inter- group differences in the body mass index variable. Consistent with this result, there was no significant difference in body mass index of individuals as a result of 6 grams / day royal jelly application for 4 weeks on healthy humans [10]. In another study conducted with royal jelly, it was determined that there was no significant difference in the body mass index variable in the intake of royal jelly for 6 months [11]. In a study in which royal jelly was given to the swimmers, it was found that there was no significant difference in the body mass index [12].

While resistance training increases strength and resilience, it also increases muscle protein synthesis and hypertrophy [13]. In this study, inter- group differences between the 2 . and 3 . measurements in the bench press, 1., 2. and 3. measurements in the squat, 2. measurement in arm curl and 2. measurement in shoulder press were significant. There was no inter-group difference in Deadlifts. Statistically significant increases were detected in the second and third measurements of the bench press, squat, arm curl, deadlifts and shoulder press movements in both groups with respect to the first measurement and the differences between all of the measurements were determined to be significant.

A randomized, double-blind, placebo-controlled study in which effect of creatinine monohydrate on anaerobic performance and maximal force was determined, indicated that loading with $20 \mathrm{~g} \cdot \mathrm{d}^{-1}$ of creatine monohydrate for 7 days increased $(5.4 \%$ increase) from the Wingate anaerobic test, but it had no effect on strength peak power or body weight [14].

In a study of weight training and the effect of glutamine supplementation in young adults aged between 18-24 years, a statistically significant increase in squat and bench press movements of both groups treated with glutamine and placebo was observed but muscular performance and body composition was not affected in any way [15]. Strength increase occurred in training men who used a six-week multi-blend performance supplement, but inter-group difference (supplement and placebo) did not occur [13]. It has been reported that when the essential amino acid / carbohydrate mixture was given following weight training, both (placebo and supplement) groups experienced increase in bench press and squat movements while the essential amino acid group had a positive effect on muscle hypertrophy and low nitrogen balance or low force [16]. In the study of protein metabolism and strength performance after the use of bovine colostrum supplementation, it was stated that the use of two weeks of bovine colostrum supplementation had no effect on strength performance [17].

During exercise, skeletal muscle glucose uptake is increased in the absence of insulin. The increase in muscle glucose uptake may be partly due to relative lack of oxygen, and it is stated that glucose uptake in the cells may increase in anaerobic conditions [18]. Although there was no difference between the placebo and the experimental groups in our study, there was a statistically significant increase in the difference between the 2 . and
3. measurements in the experimental group in insulin hormone. In a study made with royal jelly, $20 \mathrm{~g}$ royal jelly was given to the volunteers and oral glucose tolerance test was performed and a decrease in serum glucose levels observed 2 hours after royal jelly application. It has been reported that this decrease is due to insulin-like substances in the royal jelly [19].

In this study, ACTH in the placebo and experimental groups did not show any intra-group or inter-group differences. Similarly, in a 10 -week weight-training workout in different age groups (30-year-old young males, 62-year-old adults), it was stated that there was no difference in ACTH levels between age groups and over time according to baseline [20].

There was no significant inter-group and intra-group difference in the prolactin variable in our study. However, the difference between the 1 . and 3 . measurements in the placebo group in cortisol hormone was found to be significant. In another study, higher cortisol levels were reported after 5 minutes to 30 minutes of exercise after soy protein supplementation than whey protein supplementation [21]. In a study in which effect of specific protein supplements in strength / power athletes were determined on the recovery indices after acute-weight training, 7 male athletes were given 42 grams of protein supplement before and after exercise in the supplement group. When the results were evaluated, it was stated that the difference between the basal measurements at the cortisol hormone level and the other measurements was influenced by exercise, and it was emphasized that the given protein reinforcement had no effect [22].

The increase in hormone release of troxin (T4) and thyrodotrone (T3) in exercise is related to the regulation of energy balance in exercise. The thyroid gland hormones troxin and thyrodotrone have been shown to be increased with prolonged, severe exercise (type of endurance) and this increase was stated to be related to energy balance [18]. In this study, there were no significant inter-group and intra-group differences between the placebo and experimental groups, in free $\mathrm{T} 3$ and $\mathrm{TSH}$. However, it was determined that the difference in the 2 . measurement of the groups in free T4 value was significant. The severity and duration of exercise significantly affects the circulatory levels of thyroid hormone. In one study, $0-18$ to $0-9 \mathrm{~km}$ swimming or moderate severity 90 minutes cycling ergometer pedaling did not affect the thyroid concentration [23]. In another study, there was a statistically significant decrease in free T3 after intensive rowing training, but no change in T4 level occurred [24]. According to these results, it can be said that the duration, severity and frequency of the exercise types applied affect the hormonal levels.

In our study, there was no significant inter-group and intra-group difference in the LH variable. It was determined that the difference between the 1 . and 3. measurements in the FSH variable was significant in the experimental group according to the multiple comparison test (Intra-group). In a study conducted on very advanced training champion athletes, there was no significant increase in serum LH and 
FSH levels immediately after $400 \mathrm{~m}$ run. Another study suggests that there might be a decrease in the testicular response to luteinizing hormone, although there was no reduction in luteinizing hormone [25].

During training, the increase in growth hormone is less in trained individuals than in non-trained individuals [23]. In other study, emphasized that the release of plasma stress hormones (cortisol-GH-prolactin) in the usual stress states is less than the secretion in unusual stresses and emphasized that the situation may lead to an extended adaptation of the hypothalamic-hypothalamus line to long stress conditions [26]. In this study, there was no statistically significant inter-group and intra-group difference in growth hormone. Similarly, in training men who use a six-week, multi-blend performance supplement, in the study called the effect of weight training on the workings of anabolic hormones, body composition, strength and power, it is implicated that multiple mix performance supplements and weight training had no effect on serum growth hormone [13].

Although the effects of anabolic steroids on physical performance cannot be fully determined, it has been suggested that the testosterone, an anabolic steroid hormone, stimulates protein deposits and muscle growth and may provide increases in body weight, lean body mass, bench press and squat [27]. It has been reported that testosterone increases with short intensive exercise and this increase is related to blood lactate concentration [28]. There was no significant inter-group and intra-group difference in the total testosterone variables in our study. Similarly, in a study conducted in weight workouts in association with soy protein and whey protein, there was no statistically significant difference between the groups in the serum free testosterone and total testosterone after 12 weeks of weight training, so it was stated that there was no effect of supplements [29].

Testosterone levels in men have been reported to reach their highest levels immediately after weight lifting exercise [30]. Although there is a post-exercise elevation in the endurance training group, it is stated that there was a meaningful decrease in plasma total and free testosterone in the following recovery period, the decrease might change in intensity according to the strength and intensity of the exercises and the amount of calories consumed [31]. Similarly, they emphasized that increased testosterone levels during short-term exercises were reduced in longterm exercises [32].

Although studies have shown an increase in testosterone concentration immediately after exercise, this increase was expressed to decrease to the basal levels 60 minutes after exercise [33, 21]. In this study, it is thought that testosterone levels might be lowered to the basal levels at the post-exercise hours.

\section{Conclusions}

In this study, royal jelly + honey mixture used for two months did not have any adverse effects or allergic reactions on the athletes. However, it should be kept in mind that the increase in the amount of royal jelly in the diet supplements or period of usage may result in allergic reactions.

The limitation in this research is the requirement that royal jelly and honey mixtures should be given in terms of kilogram of body weight. The greater number of samples, the control of the sleep patterns of the volunteers and the control of the intake and frequency of nutrients throughout the study, the control of the physical activity level of the volunteers other than the applied training program could also strengthen the search.

As a result, in the maximal strength training performed for 8 weeks, the increase in the bench press, squat, arm curl, deadlifts and shoulder press movements of the volunteers was observed. It was seen that this increase was due to the weight training, that the royal jelly and honey supplementation did not affect the increase in weight lifted, but caused some hormonal changes in the practice. It is suggested that the amount and duration of royal jelly + honey mixture given as supplement was not enough and that royal jelly + honey mixture may be more effective in higher doses for longer periods in subsequent studies.

\section{Acknowledgments}

Erciyes University, Research Foundation has supported this research (contract grant number TDK2012-4162). The authors thank Altiparmak Food.Co. (Istanbul) for their product supports.

\section{Conflict of interest}

The authors declare no conflict of interest.

\section{References}

1. Bogdanov S. Royal jelly, bee brood: Composition, health, medicine: A Review Bee Product Science. 2012. Retrieved from: www. Bee-hexagon.net

2. Joksimovic A, Stankovic D, Joskimovic I, Molnar S, Joksimovic S. Royal jelly as supplement for young football players. Sport Science, 2009;1:62-67.

3. SarıtasN,YıldızK, BüyükipekciS, CoskunB.Effectofdifferent levels of royal jelly on biochemical parameters of swimmers. African Journal of Biotechnology, 2011; 10(52):10718-23. https://doi.org/10.5897/AJB11.1862

4. Bogdanov S, Lülmann C, Martin P, Ohe W, Russmann H, Vorwohl G. et al. Honey quality, methods of analysis and international regulatory standards. Review of the work of the
International Honey Commission. Bee World, 1999; 80, 2.

5. Hazar S, Y1lmaz G. Acute effect of submaximal treadmill exercise on immune system.: Proceeding of the 10th International Sports Science Congress; 2008 October; Bolu. Turkey; 2008. P. 23-25 (in Turkish).

6. Büyükyazı G, Turgay, F. Acute and chronic effects of continuous and widespread interval exposition exercises on some hematological parameters. Proceeding of H.Ü. Spor Bilimleri ve Teknolojisi Yüksekokulu VI. Spor Araştırmaları Kongresi, (School of Sport Sciences and Technology, VI. Sports Research Congress); 2000, November; Ankara: Turkey; 2000. P.182 (in Turkish).

7. Kraemer WJ, Ratamess NA. Physiology of resistance training: current issues. Orthopaedic Physical Therapy 
Clinics of North America, 2000; 9(4): 467-51.

8. Gökbel H, Dölek C.. Some hormonal responses to exercise. Spor Hekimliği Dergisi, 1998; 33, 87-94 (in Turkish).

9. World Health Organization. Global database on BMI (document on the Internet). ABC online; 1995 (cited 2018 Feb 1). Available from: http://apps.who.int/bmi/index. jsp?introPage $=$ intro $3 . \mathrm{html}$

10.Guo H, Saiga $\bar{A}$, Sato $M$, Miyazawa I, Shibata M, Takahata $\mathrm{Y}_{2}$ et al. Royal jelly supplementation improves lipoprotein metabolism in humans. Journal of Nutritional Science and Vitaminology, 2007; 53: 345-348. https://doi.org/10.3177/jnsv.53.345

11. Morita H, Ikeda T, Kajita K, Fujioka K, Mori, I, Okada $\mathrm{H}$, et al. Effect of royal jelly ingestion for six months on healthy volunteers. Nutrition Journal, 2012; 11: 77-82. https://doi.org/10.1186/1475-2891-11-77

12.Sarıtaş N, Yıldız K, Coşkun B, Büyükipekci S, Çoksevim B. Effect of royal jelly ingestion for four weeks on hematological blood markers on swimmers. Ovidius University Annals, Series Physical Education and Sport Science, Movement and Health, 2014; 14:196-202.

13.Ormsbee MJ, Mandler WK, Thomas DD. The effects of six weeks of supplementation with multi-ingredient performance supplements and resistance training on anabolic hormones, body composition, strength, and power in resistance-trained men. Journal of International Society of Sports Nutrition, 2012; 9: 49-55. https://doi.org/10.1186/1550-2783-9-49

14.Zuniga JM, Housh TJ, Camic CL. The effects of creatine monohydrate loading on anaerobic performance and onerepetition maximum strength. The Journal of Strength and Conditioning Research, 2012; 26:1651-1656. https://doi.org/10.1519/JSC.0b013e318234eba1

15.Candow DG, Chilibeck PD, Burke DG, Davison SK, Smith-Palmer T. Effect of glutamine supplementation combined with resistance training in young adults. European Journal of Applied Physiology, 2001; 86:142-149. https://doi.org/10.1007/s00421-001-0523-y

16. Vieillevoye S, Poortmans JR, Duchateau J, Carpentier A. Effects of a combined essential amino acids/carbohydrate supplementation on muscle mass, architecture and maximal strength following heavy-load training. European Journal of Applied Physiology, 2010;110: 479-488. https://doi.org/10.1007/s00421-010-1520-9

17.MeroA, Nykänen T, Keinänen O, Knuutinen J, Lahti K, Alen M, etal. Protein metabolism and strength performance after bovine colostrum supplementation. Aminoacids, 2005; 28: 327335. https://doi.org/10.1007/s00726-005-0179-8

18.Günay M, Kara E, Cicioğlu İ. Endocrinological Compliance to Exercise and Training. Gazi Yayınevi, 2006;1:124-126 (in Turkish)

19.Münstedt K, Bargello M, Hauenschild A. Royal jelly reduces the serum glucose levels in healthy subjects. Journal of Medicinal Food, 2009;12: 1170-1172. https://doi.org/10.1089/jmf.2008.0289

20.Kraemer WJ, Häkkinen K, Newton RU, Nindl BC, Volek JS, McCormick M. et al. Effects of heavy-resistance training on hormonal response patterns in younger vs. older men. Journal of Applied Physiology, 1999; 87: 982-992. https://doi.org/10.1152/jappl.1999.87.3.982

21.Kraemer WJ, Solomon-Hill G, Volk BM. The Effects of soy and whey protein supplementation on acute hormonal responses to resistance exercise in men. Journal of the American Collage of Nutrition, 2013; 32: 66-74. https://doi.org/10.1080/07315724.2013.770648

22.Hoffman JR, Ratamess NA, Tranchina CP. Effect of a proprietary protein supplement on recovery indices following resistance exercise in strength/ power athletes. Amino acids; 2010; 38:771-778. https://doi.org/10.1007/s00726-009-0283-2

23.Fox EL, Mathews KD. The physiological basic of physical education and athletic. W.B. Sounders Company, Philadelphia; 1988. p. 213-250.

24.Simsch C, Lormes W, Petersen KG, Baur S, Liu Y, Hackney AC, et al. Training intensity influences leptin and thyroid hormones in highly trained rowers. International Journal of Sports Medicine, 2002; 23: 422-427. https://doi.org/10.1055/s-2002-33738

25.Chandler RM, Byrne HK, Patterson JG, Ivy JL. Dietary supplementsaffect the anabolichormones afterweight-training exercise. Journal of Applied Physiology, 1994; 76: 839-845. https://doi.org/10.1152/jappl.1994.76.2.839

26.Karp L, Weizman A, Tyano S, Gavish M. Examination stress, platelet peripheral benzodiazepine binding sites, and plasma hormone levels. Life Sciences, 1989; 44: 1077-1082. https://doi.org/10.1016/0024-3205(89)90334-2

27.Fahey T.D. Anabolic-androgenic steroids: mechanism of action and effects on performance. In: Encyclopedia of Sports Medicine and Science, 1998; 123-125.

28.GökbelH,DölekÇ,BedizCŞ.KaraM,VuralH.Therelationship of lacticacid and total testesterone levels after the Wingate test. Turkish Journal of Medical Sciences, 1996; 26: 201-202. https://doi.org/10.1186/1550-2783-4-4

29.Kalman D, Feldman S, Martinez M, Krieger DR, Tallon MJ. Effect of protein source and resistance training on body composition and sex hormones. Journal of the International Society of Sports Nutrition, 2007; 4: 1-8. https://doi.org/10.1186/1550-2783-4-4

30. Weiss LM, Cureton KJ, Thompson FN. Comparison of serum testosterone and androstenedione responses to weight lifting in men and women. European Journal of Applied Physiology, 1983; 50: 413-419. https://doi.org/10.1007/BF00423247

31.Tremblay MS. Copeland JL, Vanhelder W. Effect of training status and exercise mode on endogenous steroid hormones in men. Journal of Applied Physiology, 2004; 96: 531-539. https://doi.org/10.1152/japplphysiol.00656.2003

32.Cumming DC, Brunsting LA, Strich G, Ries AL, Rebar RW. Reproductivehormoneincreasesinresponsetoacute exercisein man, Medicine \& Science in Sports Exercise, 1986; 18:369-373. https://doi.org/10.1249/00005768-198608000-00001

33.KraemerWJ, Volek JS, Bush JA, Putukian M, Sebastianelli WJ. Hormonal responses to consecutive days of heavy-resistance exercise with or without nutritional supplementation. Journal of Applied Physiology, 1998;85: 1544-1555. https://doi.org/10.1152/jappl.1998.85.4.1544 


\section{Information about the authors:}

Büyükipekçi S. (Corresponding author); Asst. Prof; http://orcid.org/0000-0001-8724-5374; sbuyukipekci@konya.edu.tr; Meram Vocational School, Necmettin Erbakan University; Necmettin Erbakan Üniversitesi, Meram Meslek Yüksekokulu, Konya, Turkey.

Sarıtaş N.; Assoc. Prof.; http://orcid.org/0000-0003-3402-6498; nsaritas@erciyes.edu.tr; Sports Sciences Faculty, Erciyes University; Erciyes Üniversitesi Spor Bilimleri Fakültesi, Kayseri, Turkey.

Soylu M.; Asst. Prof.; http://orcid.org/0000-0001-6968-8729; meltemboh@gmail.com; Faculty of Health Sciences, Nutrition and Dietetic Department, Biruni University; 10. Yıl Caddesi Protokol Yolu No: 45, 34010 Topkapı / İstanbul, Turkey.

Mıstık S.; Prof. Dr.; http://orcid.org/0000-0003-0657-3881; smistik@erciyes.edu.tr; Medical Faculty, Family Medicine Department, Erciyes University; Erciyes Üniversitesi Tıp Fakültesi, Aile Hekimliği Anabilim Dalı, Kayseri, Turkey.

Silici S.; Prof. Dr.; http://orcid.org/0000-0003-2810-2917; sibelsilici@gmail.com; Faculty of Agriculture, Department of Agricultural Biotechnology, Erciyes University; Erciyes Üniversitesi, Ziraat Fakültesi, Tarımsal Biyoteknoloji Bölümü, Tarımsal Araştırmalar Bölümü 38039 - Kayseri, Turkey.

Cite this article as: Büyükipekçi S, Sarıtaş N, Soylu M, Mıstık S, Silici S. Effects of royal jelly and honey mixture on some hormones in young males performing maximal strength workout. Physical education of students, 2018;22(6):308-315. doi:10.15561/20755279.2018.0605

The electronic version of this article is the complete one and can be found online at: http://www.sportedu.org.ua/index.php/ PES/issue/archive

This is an Open Access article distributed under the terms of the Creative Commons Attribution License, which permits unrestricted use, distribution, and reproduction in any medium, provided the original work is properly cited (http:// creativecommons.org/licenses/by/4.0/deed.en).

Received: 24.09.2018

Accepted: 22.10.2018; Published: 26.12.2018 